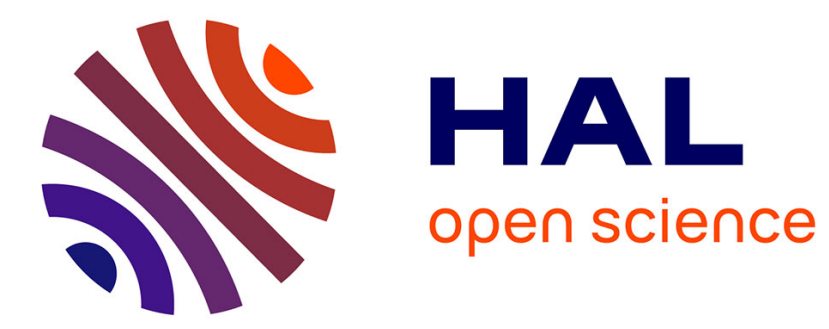

\title{
Case Studies of Participatory Design
}

Mandy Tawalbeh, Ralph Riedel, Samuel Horler, Egon Müller

\section{To cite this version:}

Mandy Tawalbeh, Ralph Riedel, Samuel Horler, Egon Müller. Case Studies of Participatory Design. IFIP International Conference on Advances in Production Management Systems (APMS), Sep 2017, Hamburg, Germany. pp.159-167, 10.1007/978-3-319-66926-7_19 . hal-01707238

\section{HAL Id: hal-01707238 \\ https://hal.inria.fr/hal-01707238}

Submitted on 12 Feb 2018

HAL is a multi-disciplinary open access archive for the deposit and dissemination of scientific research documents, whether they are published or not. The documents may come from teaching and research institutions in France or abroad, or from public or private research centers.
L'archive ouverte pluridisciplinaire HAL, est destinée au dépôt et à la diffusion de documents scientifiques de niveau recherche, publiés ou non, émanant des établissements d'enseignement et de recherche français ou étrangers, des laboratoires publics ou privés. 


\title{
Case Studies of Participatory Design Comparison of methodologies in factory planning
}

\author{
Mandy Tawalbeh, Ralph Riedel, Samuel Horler, Egon Müller \\ Department of Factory Planning and Factory Management \\ Institute of Management and Factory Systems \\ Chemnitz University of Technology, Germany \\ ( $\{$ mandy.tawalbeh; ralph.riedel $\}$ amb.tu-chemnitz.de)
}

\begin{abstract}
Nowadays, user integration is focused at an early stage of the innovation process by using methods of open innovation, especially of participatory design. The methods LEGO® SERIOUS PLAY®, gamification with LEGO® MINDSTORMS $®$ as well as interactive workshops are investigated successfully concerning their suitability. This evaluation relates to various objectives and applications by dint of three case studies relating to factory planning - merged technologies, digitalization and professional education. The comparison of the used methods shows the need of a context- and objective-related preselection of methodological approaches of participatory design to tap their full potentials.

Keywords: Open Innovation, Participatory Design, Prototyping, LEGO® SERIOUS PLAY®, LEGO® MINDSTORMS®, Factory Planning, Merging Technology, Digitalization, Education
\end{abstract}

\section{$1 \quad$ Introduction and motivation}

The increasing significance of innovations [1] results either from the rising market demands [2] or the need to improve products and processes by consideration of new technologies and digital approaches [3,4]. Innovations are only successful when the provided products and services sate the wants of the end users by gaining an additional value [5]. Hence, user-integrated innovation is a key competitive factor for the design of innovative products, services and processes [2] supporting the implementation of new technologies in a working factory and their consideration in the planning process. Hence, methods of open innovation - especially of participatory design - are investigated to identify their application fields in the context of factory planning and management.

Currently, there is a big variety of methods whose applications are not concerted with the innovation process. Different procedures should be selected by focusing the targeted objectives of the innovation process. Three case studies are used to represent the characteristics of different applications and demands for appropriate methods. LEGO ${ }^{\circledR}$ SERIOUS PLAY®, LEGO ${ }^{\circledR}$ MINDSTORMS ${ }^{\circledR}$ and an interactive workshop are investigated related to their suitability and conditions of use. The findings lead to 
the design process for dealing with new technologies by varying initial situations.

This article starts with a literature review referring to the disciplines of open innovation and describes the diversity of methods of participatory design with focus on process innovation. Product innovation will be neglected. Subsequently, three case studies represent the potentials of different methodological approaches in comparison.

\section{Open Innovation}

Innovations are the driver of the national economics [6] by generating new ideas as basis for the creation of new products, processes and services. The importance of a product innovation is its impact on the competitive strategy of the enterprise. Process innovations increase the economic efficiency of the production by improving business and production processes. New ideas for innovations result either from user or customer needs or from new production procedures and technologies.[7] Hence, it is necessary to study demands across the enterprise with open innovation approaches considering internal as well as external ideas in the development of innovative processes. [8] The phases of an innovation process are shown in Fig. 1.

Fig. 1. Innovation circle (related to [9])

\footnotetext{
Rapid Innovation | Product Launches | Customer Response | Reduce Cost | Realiable Products

ideate $\Rightarrow$ define $\Rightarrow$ explore $\Rightarrow$ validate $\Rightarrow$ build $\Rightarrow$ test $\Rightarrow$ transfer
}

Participatory Design is a discipline of open innovation during the ideation phase of the innovation process and describes the involvement of different stakeholders in the design process to increase the degree of need satisfaction of the end users.[10] In the field of factory planning, it is necessary to integrate stakeholders directly representing their actual needs of functional and designing features. Hence, the methods of Participatory Design have to be investigated in detail. Muller and Kuhn [11] provide an overview of methodological approaches of Participatory Design related to their utilization point along the product life cycle and their stakeholder participation (shown in Fig. 2).

Fig. 2. Overview on methodological approaches of participatory design (related to [11])

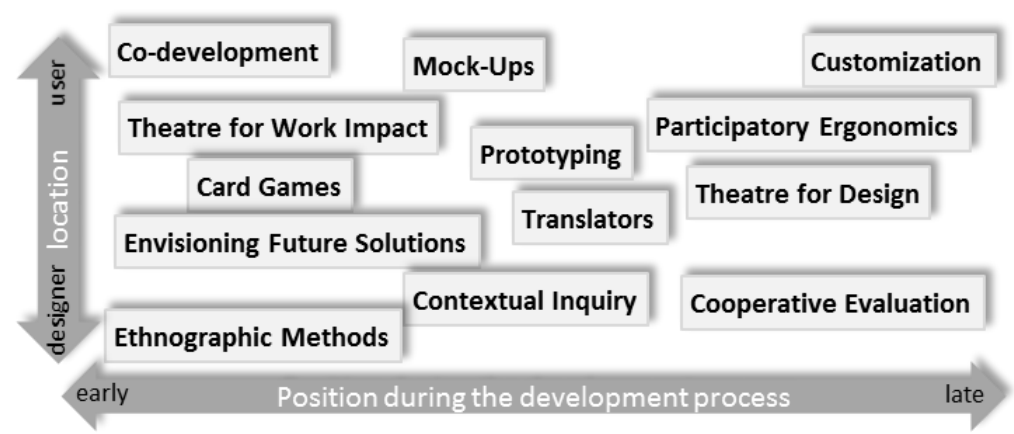

The diversity of methods in Participatory Design can be divided in five categories: 
gamification, prototyping, creativity techniques, dynagrams and image schemes.

Gamification is used to understand the context playfully [12]. Examples of methods are LEGO® SERIOUS PLAY® or scenario analysis. LEGO® SERIOUS PLAY® is an innovative hands-on and minds-on method based on metaphorical thinking to improve the understanding of processes. This is achieved by interpretation of alternatives and significances, and discussions in the group.[13] Scenario Analysis describes the investigation of future developments based either on varying ways to reach desired situations or on varying expectations of progressing.[14] LEGO® MINDSTORMS® rebuilds the production structure in a scaled Lego model representing processes with the aid of programming, and technical components.[15]

Prototyping describes the creation of the first of its manner with reduced demands related to design, function and quality compared with the end product / process to identify weaknesses. Prototypes are physical or virtual models of products or processes. Physical product prototypes are realized by rough or rapid prototyping, while virtual product prototypes are done by CAD modelling and drawing. [16, 17]

A process prototype represents the main activities of a process considering their interdependencies. The level of detail is geared to the original process. Hence, the complexity increases.[18] Process prototypes can be implemented physically by using LEGO® MINDSTORMS $®$ or Cardboard Engineering for example [15] and virtually by simulating. Simulation is the key method of systems dynamics used to investigate the characteristics of a social, economic, biological and ecological system. Such a system is defined by dynamic and temporary interdependencies between system components and their environment. [19]

Creativity techniques are well-known methodological approaches to gather ideas by open-minded and unlimited thinking. Typical methods are Mind Mapping, Morphological Box and Brainwriting.[20]

Dynagrams are defined as interactive visualizations based on a diagram. They allow users to create, change and extend collaboratively products or processes. The analysis and investigation of scenarios, the yield of conclusions, the preparation of experiences as well as the evaluation and decision-making are enabled. Common dynagrams are the Roger Dynagram, the Sankey Diagram and the Confluence Diagram.[21]

Image schemes are abstract representations of recurring dynamic patterns of interactions to structure people's view on the world. The basis are abstractions being more tangible than symbols but less realistic than pictures. They represent sensorimotor contours consisting of information which can be visual, haptic, kinesthetic or acoustical. Hence, image schemes are a metaphorical approach originating from linguistic contexts that is now extended into non-linguistic fields like cognitive psychology.[22]

\section{$3 \quad$ Methodological investigation and case studies}

All the different methods of Participatory Design are suitable for varying use cases in factory planning to tap their full potential. Hence, it was necessary to classify them on their objectives. Three main objectives of participatory design methods result from 
the knowledge basis of the single participants. (1) Acquisition of knowledge, i.e. participants don't know the technologies yet and get to know them by acquiring knowledge related to these new technologies. (2) Identification and analysis of potentials i.e. participants know the new technologies, but neither did they consider their implementation nor any analysis of potentials in their enterprises. (3) Prototypical realization i.e. participants develop a prototype for the identified application fields.

For these categories, based on design objectives, three case studies are investigated varying in their application fields and selected methods of participatory design. The suitability of these methods is analyzed by additional influences resulting from the innovation context and the integrated participants. After the workshop, the fit of the methods was assessed by analyzing the initial situation, while considering the quality of the results, too. The comparison of the methods is based on deduced criteria. The three used approaches - the interactive workshop, LEGO® SERIOUS PLAY® and LEGO® MINDSTORMS $®$ - are evaluated and possible application fields are deduced.

\subsection{Case study 1: Merged technologies to produce hybrid components}

The German Federal Cluster of Excellence MERGE studies the combination of different technologies like plastics injection molding and metal die casting to produce resource efficiently hybrid components for lightweight conveyor systems in a large-scale manner. Hence, factory planning deals with the upcoming challenge of space-concentration requiring optimization of logistics processes. A modified logistics concept and a logistics planning procedure have been created which bring up changing conditions.

A workshop (described in $[23,24]$ ) was used to validate the new approaches and to offer a frame for educational contexts. It consists of two parts: (1) challenges of merged production processes and (2) knowledge transfer for dimensioning a load carrier.

In the first workshop part "challenges of merged production processes", the participants present, analyze and investigate synergy effects of merged production processes. This is based in the previous introduction of plastic injection molding and metal die casting. Subsequently, synergy effects of production and logistics processes can be identified and investigated. The results of this first part concentrate on technological aspects. The identified synergy effects are:

Material flows on a modular constructed tool as well as on several clamping units and robots for handling facilitates a faster change of cavities to deal with small production batches. Whereas, the transportation complexity decreases. The big differences of melting temperatures of metal and plastics can be reduced by using zinc alloy instead of aluminum alloy. Thereby, the energy demand decreases.

The second part "knowledge transfer for dimensioning a load carrier" is based on the definition of needs and attributes resulting from the chosen material which has to be conveyed. These needs and attributes include handling geometries, work flows, operations and premises of logistics. Afterwards, workshop participants design a load carrier and define its demands on transportation and material supply. They create different variants of load carriers with the aid of a load carrier morphology being evaluated by a cross-impact matrix and an efficiency analysis. One result is the identification of the 
best variant dimensioned afterwards related to technical or structural parameters, type and size in conjunction with the existing setting restrictions.

\subsection{Case study 2: Transfer of digitalization knowledge}

The German promotion initiative "Mittelstand 4.0 - Agentur Prozesse" is focused on the digitalization of resource and process management. The main objective is the qualification of information multipliers who are enabled to assist SMEs as well as handicraft enterprises. Hereby, the LEGO ${ }^{\circledR}$ SERIOUS PLAY® method is used.[25]

In this context, LEGO ${ }^{\circledR}$ SERIOUS PLAY® aims at the establishment of a shared comprehension of digitalization. A fictive enterprise builds the frame where each participant puts oneself in the position of a certain role. After a short theoretical introduction and warm up with Lego, each participant designs a future vision of the enterprise as most digitalized SME in the year 2020 from his point of view. They accentuate special features in comparison to the rival businesses. Concrete realization actions are carved out for the working area of his role in the enterprise. Additionally, possibilities to integrate users and colleagues into the digitalization of the processes are reflected. The resulting single models are presented to the other participants by storytelling.

Subsequently, a collective model is created in the group by combing the single models. It is important that every participant is represented in his role. The design has to be accepted by everyone and new ideas are also considered. Finally, this collective model is presented by one or more participants via storytelling. This presentation is filmed.

Additionally, the systems environment has to be analyzed to identify external influences considered as small single Lego models. Their relations to the main system and its components are rebuilt with their positions on the table. The participants are supposed to move around the table to be inspired by different perspectives on the system.

The analysis of potential future events with positive or negative effects follows. Therefore, the creativity technique approach of issue cards is used. The most important scenario has to be identified in a group discussion which will be investigated concerning its influences and consequences for the system. That's the finishing point to work with the Lego model.

Finally, each participant changes his role from the fictive enterprise to the multiplier role and all findings of the design process being relevant for the work of multipliers are collected. Possible recommended actions and starting points for digitalization are assembled creating the foundation for the support of centers of excellence and enterprises. The five most important approaches are highlighted.

\subsection{Case study 3: Professional education in factory planning}

The professorship factory planning and management at Chemnitz University of Technology offers several subjects to students for specialized knowledge transfer based on theoretical learning procedures which don't represent the actual key competence of interdisciplinary thinking and working with the entire factory. Therefore, the course "Methods of Systems Engineering" combines different disciplines and the students get the chance to connect abstract theoretical knowledge within a practical context. 
In this practical context, a connection between an intermediate store and two machines for laser cutting has to be analyzed, optimized, planned and realized prototypically by minimizing the work in progress of semi-finished goods.

Students create a technical solution in a team under consideration of given and arising restrictions. This task improves the ability to solve problems in a creative and innovative procedures by using group synergies.

At the beginning, the students have to analyze different given process variants to select their favorite one by applying queuing theory. Additionally, the project has to be planned by focusing on team building with different competencies and planning the project organization, structuring of the context and defining demands.

In the execution phase, the main task is to generate a model of the entire production system with LEGO ${ }^{\circledR}$ MINDSTORMS ${ }^{\circledR}$. The sub systems are solved step by step in different variants. Their tests and evaluations are done continuously to identify the favorite solution by using predefined criteria.

Besides the model building tasks, the project has to be controlled related to the achievement of the objectives - time and progress. The procedure as well as the results are documented continuously.

\section{Comparison of the Methods}

The three case studies access different methodological approaches to integrate users in the innovation process. Case study 1 uses creativity techniques to collect ideas and acquire knowledge. In contrast, a combination of methods builds the basis for case study 2 where the open-minded idea generation is realized by LEGO® SERIOUS PLAY® and results are collected and prioritized by creativity techniques like storytelling. In case study 3 , the participants are supposed to design a realistic prototype with LEGO® MINDSTORMS®.

The main differences of the used methodological approaches are identified in innovation need as well as the abstraction and design level.

The interactive workshop with creativity techniques is suitable for case study 1 to acquire knowledge because it serves as tool for further education regarding merged production processes, the new logistics concept and general methods of factory and logistics planning. The workshop is accepted as suitable tool for further education.

In case study 2 , the participants with varying knowledge background aim at the creation of a shared understanding of digitalization and investigation of technological potentials. The basis is an open-minded team working progress achievable with LEGO® SERIOUS PLAY ${ }^{\circledR}$ which allows creative thinking and interpreting of common structures. During discussions and storytelling of the participants, everybody is able to share knowledge and experiences. Hence, LEGO® SERIOUS PLAY® supports successfully the open-minded innovation process whose results are prepared by additional using of creativity techniques.

In case study 3 , students work in a creative but realistic way to design a prototype of a factory by using project management and synergies from team work. Idea generation refers to finding new realization approaches to solve problems during the modeling 
process. Technological possibilities are known. The realistic representation of a factory system supports the understanding of the theoretical knowledge from lectures. Students can integrate their own ideas into the model under consideration of restrictions. Hence, LEGO ${ }^{\circledR}$ MINDSTORMS $®$ is an applicable method in the professional education.

More detailed characteristics of each designing process are shown in table 1.

Table 1. Characteristics of the different case studies

\begin{tabular}{|c|c|c|c|c|}
\hline & Criteria & Case study 1 & Case study 2 & Case study 3 \\
\hline \multirow{3}{*}{ 葛 } & $\begin{array}{l}\text { Innovation } \\
\text { need }\end{array}$ & $\begin{array}{l}\text { Knowledge } \\
\text { acquisition }\end{array}$ & $\begin{array}{c}\text { shared under- } \\
\text { standing \& } \\
\text { potential analysis }\end{array}$ & $\begin{array}{c}\text { idea generation \& } \\
\text { prototypical } \\
\text { realization }\end{array}$ \\
\hline & $\begin{array}{l}\text { Innovation } \\
\text { level }\end{array}$ & new creation & $\begin{array}{c}\text { new creation / } \\
\text { changing }\end{array}$ & $\begin{array}{c}\text { new creation / } \\
\text { changing }\end{array}$ \\
\hline & $\begin{array}{l}\text { Planning } \\
\text { level }\end{array}$ & strategic & strategic & tactical \\
\hline \multirow{2}{*}{ 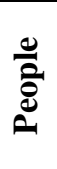 } & $\begin{array}{l}\text { Knowledge } \\
\text { basis }\end{array}$ & homogeneous & heterogeneous & heterogeneous \\
\hline & $\begin{array}{l}\text { Professional } \\
\text { background }\end{array}$ & homogeneous & homogeneous & homogeneous \\
\hline \multirow{2}{*}{ : } & $\begin{array}{l}\text { Abstraction } \\
\text { level }\end{array}$ & realistic & metaphoric & realistic \\
\hline & Design level & traditional & creative & creative \\
\hline
\end{tabular}

All three case studies achieve the targeted objectives with the aid of the pre-selected methods of participatory design what their suitability affirm.

\section{Summary}

The significance of Participatory Design methods increases in the process innovation. Hence, three case studies were investigated in the application field of factory planning. Every case study has its own characteristics and demands towards user-integrated innovation processes improving the quality of the results. The affirmation of the suitability of the preselected user-integrated methods was successfully for all case studies. In summary, the interactive workshop with creativity techniques supports the acquisition of knowledge. In contrast, LEGO ${ }^{\circledR}$ SERIOUS PLAY® combined with creativity techniques is used to design innovative and open-minded ideas or solutions while getting a shared knowledge base in the team. Finally, prototyping improves the professional education at university because theoretical knowledge is transferred into a practical context. As conclusion, the results can be used as data base for the development of a systematical approach to select a suitable method of participatory design for different use cases. The systematical approach should be based on the consideration of targeted effects, characteristics of content and participants. Hence, a suitable approach of participatory design has to be selected to tap its full potential. 


\section{$6 \quad$ Literature}

1. Franke, N.; Schirg, F.; Reinsberger, K. (2016): The frequency of end-user innovation: A reestimation of extant findings. In: Research Policy 45 (8), pp. 1684-1689

2. Reguia, C. (2014): PRODUCT INNOVATION AND THE COMPETITIVE ADVANTAGE. In: European Scientific Journal (vol. 1), pp. 140-157.

3. Radziwon, A.; Bilberg, A.; Bogers, M.; Madsen, E. S. (2014): The smart factory: exploring adaptive and flexible manufacturing solutions, Procedia Eng. 69, pp. 1184- 1190.

4. Lasi, D.H.; Fettke, P.D.P.; Kemper, P.D.H.-G.; Feld, D.-I.T.; Hoffmann, D.-H.M. (2014): Industry 4.0, Bus. Inf. Syst. Eng. 6, pp. 239-242.

5. Cavaye, A.L.M. (1995); User participation in system development revisited, Inf. Manag. 28, pp. 311-323.

6. Bauer, P. C. (2013): Innovation als Treiber der Wirtschaft. Retr. 20.02.2017; http://www.exonmiesuisse.ch/de/artikel/innovation-als-treiber-der-wirtschaft

7. Gakkai, N. K. (1988): Innovation and Management: International Comparisons. Berlin: Walter de Gruyter.

8. Gassmann, O.; Enkel, E. (2006): Open Innovation: Externe Hebeleffekte in der Innovation erzielen. In: Führung + Organisation (3), pp. 132-138.

9. NurturEnergy: Open Innovation. Retr. 20.2.2017 ; http://www.nurturenergy.com/model.html

10. Colin, Lucila Mercado; Chavez, Alejandro Rodea (2015): User's Typology for Designing. In: Procedia Manufacturing 3, S. 6005-6012.

11. Muller, M. J.; Kuhn, S. (1993): Participatory design. In: Commun. ACM 36 (6), pp. 24-28.

12. Riedel, J. C. K. H.; Feng, Y.; Azadegan, A.; Romero, M.; Usart, M.; Baalsrud Hauge, J. (2014): Measuring the Commercial Outcomes of Serious Games in Companies - A Review. In: Springer International, pp. 176-191.

13. Carpenter, Jacque (2008): Metaphors in qualitative research: shedding light or casting shadows? In: Research in nursing \& health 31 (3), pp. 274-282.

14. Hassani, B. (2016): Scenario Analysis in Risk Management: Theory and Practice in Finance. Berlin, Heidelberg: Springer Verlag.

15. Biermann, K. (2013). Lego EV3: Lego Mindstorms ist kein Kinderspielzeug. Retr. 22.08.2016; http://www.zeit.de/digital/games/2013-09/lego-mindstorms-ev3.

16. Geuer, A. (1996). Rapid Prototyping in der Produktentwicklung. Berlin: Springer.

17. Trossin, H.-J. (1999). Nutzung der Ähnlichkeitstheorie zur Modellbildung in der Produktionstechnik. München: Herbert Utz Verlag.

18. Deutsches Institut für Normung. (1981). DIN 66201 Prozessrechensysteme.

19. Forrester, J. (1968). Industrial Dynamics - After the First Decade, in MgmSc 14, pp. 398-415.

20. Mesquita, A. (2011): Technology for Creativity and Innovation: Tools, Techniques and Applications: Tools, Techniques and Applications. Hershey: IGI Global.

21. Eppler, M. J.; Kernbach, S. (2016): Dynagrams: Enhancing design thinking through dynamic diagrams. In: Design Studies 47, pp. 91-117.

22. Hurtienne, Jörn; Blessing, Luciënne: DESIGN FOR INTUITIVE USE - TESTING IMAGE SCHEMA THEORY FOR USER INTERFACE DESIGN.

23. Wagner, U., Riedel, R., Müller, E., \& Kimme, F. (2013). Planning of Logistics of Large-scaleProduction of Metal-plastic-hybrid Components. Procedia CIRP, 17, 600-605.

24. Merkel, A.; Dotzer, A.; Brig, T.; Lehmeyer, M.; Müller, E. (2014): Logistikplanung im Bereich fusionierter Produktionsprozesse von Hybridbauteilen.In: TBI2014, Wissenschaftliche Schriftenreihe des IBF, Sonderheft 20, TU Chemnitz, pp. 144-156.

25. Schneider, H.: Mittelstand 4.0 - Agentur Prozesse. Retr. on 20.02.2017; http://www.prozessemittelstand.digital/ 